\title{
Utjecaj reformi tržišta rada na ekonomsku aktivnost u Europskoj uniji: kratkoročni troškovi i dugoročne koristi
}

Basarac Sertić, Martina; Čeh Časni, Anita; Vučković, Valentina

Source / Izvornik: Odabrani prijevodi, 2015, 6, 1 - 20

Journal article, Published version

Rad u časopisu, Objavljena verzija rada (izdavačev PDF)

https://doi.org/10.3326/op.29

Permanent link / Trajna poveznica: https://urn.nsk.hr/urn:nbn:hr:242:317738

Rights / Prava: Attribution-NonCommercial-NoDerivatives 4.0 International/ImenovanjeNekomercijalno-Bez prerada 4.0 međunarodna

Download date / Datum preuzimanja: 2023-04-26

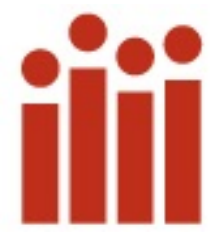

Repository / Repozitorij:

Institute of Public Finance Repository

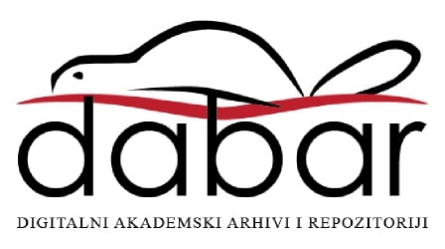


Institut za

javne financije

Smičiklasova 2I | Zagreb

www.ijf.hr | ured@ijf.hr

T: oI/4886-444 | F: OI/48I9-365

\section{ODABRANI}

\section{PRIJEVODI}

ISSN $1847-7445$

BR. 29/I5

citirati: Basarac Sertić, M., Čeh Časni, A. i Vučković, V. 2015. Impact of labour market reforms on economic activity in European Union: short term costs and long term benefits. Financial Theory and Practice, 39 (I), str. 83-I07.

http://www.fintp.hr/upload/files/ft p/20I5/I/basarec_ceh_vuckovic.pdf

Svi Odabrani prijevodi dostupni su na: http://www.ijf.hr/hr/publikacije/ca sopisi/I2/odabrani-prijevodi/III/

\section{UTJEGAJ REFORMI TRŽIŠTA RADA NA EKONOMSKU AKTIVNOST U EUROPSKOJ UNIJI: KRATKOROČNI TROŠKOVI I DUGOROČNE KORISTI}

\author{
Dr.Sc. MARTINA BASARAC SERTIĆ ${ }^{*}$ ČLANAK ${ }^{* *}$ \\ DR.SC. ANITA ČEH ČASNI ${ }^{*}$ \\ Dr.Sc. VALENTINA VUČKOVIĆ \\ JEL: J88, C33, C54, HiI \\ DOI: $10.3326 /$ op.29
}

\section{SAŽETAK}

Osnovni cilj ovog rada bio je kvantificirati dugoročni i kratkoročni utjecaj reformi tržišta rada na ekonomsku aktivnost u zemljama članicama Europske unije, uključujući Hrvatsku. Stoga je primijenjen združeni procjenitelj aritmetičke sredine grupe (PMG) za razdoblje od 200o. do 20II. godine. Prije izvođenja dinamičke panel analize na temelju PMG procjenitelja, provedeni su testovi jediničnog korijena, kao i testovi panel kointegracije. Prema empirijskim rezultatima, reforme tržišta rada u dugom roku značajno utječu na BDP per capita, te imaju statistički signifikantan pozitivan predznak. Nadalje, u kratkom roku, reforme tržišta rada također imaju statistički značajan, ali negativan utjecaj na BDP per capita, uz značajnost ostalih kontrolnih varijabli (industrijske proizvodnje i stope aktivnog stanovništva). Uz ekonometrijsku analizu, prikazan je i pregled empirijskih $i$ teorijskih istraživanja o reformama tržišta rada u razvijenim $i$ tranzicijskim zemljama, te u zemljama u razvoju.

Ključne riječi: ekonomska kriza, reforme tržišta rada, Europska unija, združeni procjenitelj aritmetičke sredine grupe

Autorice zahvaljuju dvojici anonimnih recenzenata na korisnim sugestijama koje su pridonijele poboljšanju članka.

Primljeno: I. lipnja 2014.

Prihvaćeno: 7. studenog 2014.

Rad je prijavljen za godišnju nagradu "Zaklade prof. dr. Marijan Hanžeković” za 2OI4. godinu.

Martina BASARAC SERTIĆ

Hrvatska akademija znanosti i umjetnosti, Strossmayerov trg 2, Ioooo Zagreb

e-mail: mbasarac@hazu.hr

Anita ČEH ČASNI

Ekonomski fakultet u Zagrebu, Trg J. F. Kennedyja 6, Ioooo Zagreb

e-mail: aceh@efzg.hr

Valentina VUČKOVIĆ

Ekonomski fakultet u Zagrebu, Trg J. F. Kennedyja 6, Ioooo Zagreb

e-mail: vvuckovic@efzg.hr 


\section{UVOD}

U Europskoj uniji (EU), u razdoblju od 2008. do 20I3. godine, kao posljedica gospodarske i financijske krize, izgubljeno je gotovo deset milijuna radnih mjesta. Međutim, utjecaj krize na tržište rada znatno je varirao među zemljama Europske unije te rezultirao ukupnom nezaposlenošću u rasponu od 5,3\% u Njemačkoj do 26,4\% u Španjolskoj (podaci za 2013.). Navedene razlike mogu se samo djelomično objasniti razlikama u usporavanju gospodarske aktivnosti u pojedinim zemljama, te se rasprave trenutno preusmjeravaju prema razumijevanju uloge različitih čimbenika na tržištu rada kao i njihove implikacije na buduća ekonomska kretanja (ECB, 20I2.). Istovremeno, sve se više zagovara provođenje strukturnih reformi s ciljem povećanja fleksibilnosti na tržištu rada.

Reforme tržišta rada koje su predmet ovog istraživanja, intenzivno se proučavaju kako s teorijskog tako i s empirijskog aspekta na različitim uzorcima zemalja i primjenom različitih metodologija. Unatoč tome, ovaj rad doprinosi području istraživanja kroz analizu učinka reformi na razinu ekonomskih aktivnosti svih zemalja članica EU-a, uključujući i Hrvatsku. U tom su smislu, specifični ciljevi rada sljedeći: (I) analizirati utjecaj reformi tržišta rada na gospodarsku aktivnost u EU-28, te (2) istražiti postoje li razlike između I5 "starih" i I3 "novih” zemalja članica EU-a. U tu svrhu, primijenjen je združeni procjenitelj aritmetičke sredine grupa (engl. pooled mean group estimator - PMG estimator) prema Pesaran, Shin i Smith (1999.).

Ostatak rada organiziran je na sljedeći način. Poglavlje 2 pruža pregled izabranih empirijskih dokaza i teorijskih argumenata iz literature koja se bavi reformama na tržištu rada. U poglavlju 3 dan je deskriptivni opis reformi tržišta rada u zemljama članicama EU-a koristeći se dvjema bazama reformi - LABREF i Fraser Institute - koje u kombinaciji daju uvid u reformsku aktivnost zemalja. Nadalje, poglavlje 4 posvećeno je opisu primijenjene metodologije, kao i razlozima koji stoje iza izbora PMG procjenitelja. Poglavlje 5 sadrži rezultate provedene ekonometrijske analize i njihovu interpretaciju. Konačno, poglavlje 6 daje zaključna razmatranja i donosi neka ograničenja postojećeg te preporuke za buduća istraživanja.

\section{PREGLED DOSADAŠNJIH ISTRAŽIVANJA UČINKA REFORMI TRŽIŠTA RADA}

U postojećoj literaturi općenito, postoji generalni konsenzus o nužnosti provođenja strukturnih reformi s ciljem poboljšanja općeg gospodarskog napretka zemalja. Međutim, postoji jaz između teorijskih rasprava o potencijalnim koristima reformi s jedne (MMF, 2004.), te rezultata specifičnih empirijskih analiza koje ukazuju na heterogene rezultate s druge strane (za detalje vidjeti Babetskii i Campos, 2007.). Dok su reforme bile uspješne u pojedinim zemljama, $u$ nekima nisu dovele do željenih ishoda pa se nameće pitanje utječu li reforme na gospodarski napredak zemalja. Važno je pritom napomenuti da nema univerzalnog "recepta" za provođenje reformi te da one moraju biti prilagođene specifičnim okolnostima u pojedinim zemljama i temeljiti se na kvalitetnim istraživanjima po pitanju njihovih konačnih ishoda (Bergsten i Williamson, 1994.). Naime, temeljita ekonomska analiza reformskih učinaka može dati koristan uvid u moguće dugoročne učinke reformi na ekonomske rezultate, kao i uvid u proces prilagodbe nakon provođenja određene reforme, te potencijalne efekte prelijevanja među zemljama (Arpaia et al., 2007.).

Stoga je u nastavku dan selektivni prikaz novije literature o reformama tržišta rada te su opisani različiti empirijski pristupi koji se koriste za istraživanje povezanosti između reformi tržišta rada i gospodarskog rasta i razvoja. 
U tom smislu, Barnes et al. (20I3.) naglašavaju da se najveće koristi za BDP po stanovniku u dugom roku mogu ostvariti provedbom reformi koje bi povećale konkurenciju na tržištu proizvoda, smanjile razinu i/ili trajanje naknada za nezaposlene, "oslabile” propise o zaštiti zapošljavanja i slično. Međutim, iako postoji opći konsenzus u vezi prednosti različitih strukturnih reformi u dugom roku, moraju se uzeti u obzir i potencijalni kratkoročni troškovi povezani s reformama. Stoga ovaj aspekt istraživanja treba detaljnije analizirati, budući da kratkoročni troškovi mogu dovesti do kasnijeg poništavanja određenih reformi u procesu njihove implementacije.

Cacciatore, Duval i Fiori (20I2.), primjenom DSGE modela istražuju kratkoročne učinke reformi tržišta rada i tržišta proizvoda. Iako pokazuju da reforme stimuliraju rast već u kratkom roku, neke reforme rezultiraju i povećanjem nezaposlenosti, čime kratkoročno uzrokuju i velike troškove. Konkretno, reforma zaštite radnih mjesta u početku povećava otpuštanje više nego što stvara radna mjesta. Nadalje, reforma tržišta proizvoda također može privremeno dovesti do ukidanja radnih mjesta, jer za smanjenje i preraspodjelu otpuštenih radnika treba vremena. Međutim, primjena širokog izbora mjera reformi tržišta rada i proizvoda omogućuje vladama da smanje i/ili ublaže takve prijelazne troškove. Autori zaključuju da je potrebno nekoliko godina kako bi se reforme isplatile, što se djelomice može objasniti činjenicom da se njihove prednosti materijaliziraju kroz ulazak poduzeća i povećano zapošljavanje, od kojih su oba postupni procesi, dok je svaka reforma otpuštanja zaposlenih neposredna.

Nadalje, prema istraživanju OECD-a (2012.), dok neke strukturne reforme mogu prilično brzo potaknuti rast, s druge strane postoje reforme koje mogu biti štetne u "lošim” vremenima. Specifično, s aspekta reformi na tržištu rada, Bouis et al. (2012.) na temelju empirijske analize provođenja strukturnih reformi u OECD zemljama u posljednjih 30 godina, ističu da se reforme (posebno iz područja naknada nezaposlenima i zaštite zaposlenja) brže isplate $u$ dobrim nego li $u$ lošim vremenima, te da mogu rezultirati i značajnijim kratkoročnim gubicima u ekonomijama koje su u recesiji. Također naglašavaju da se koristi reformi vide tek dugoročno.

Gomes et al. (20II.), primjenom dinamičkog modela opće ravnoteže, procjenjuju makroekonomske učinke povećanja konkurencije na tržištima rada i usluga u Njemačkoj i ostatku eurozone, te alternativno, u Portugalu (kao maloj ekonomiji) i ostatku eurozone. Glavni rezultati upućuju na to da: (I) postupna primjena reformi u razdoblju od pet godina omogućuje dostizanje nove razine outputa $u$ dugom roku za sedam godina, (2) koordinacija reformi među zemljama omogućuje dodatne pogodnosti za svaku zemlju u eurozoni (tzv. efekti prelijevanja), i konačno (3) koordinacija među zemljama je ključna za postizanje homogenijih ekonomskih rezultata (odnosno, koordinacija rezultira većim i ravnomjernije distribuiranim pozitivnim učincima).

Bouis i Duval (20II.) ispituju utjecaj strukturnih reformi tržišta proizvoda i tržišta rada u trajanju od 5 do Io godina na potencijalni BDP. Rezultati njihova istraživanja pokazuju da reforme na tržištu proizvoda mogu povećati razinu ukupne produktivnosti rada za nekoliko postotaka tijekom razdoblja od Io godina u OECD zemljama, te za više od $5 \%$ u većini zemalja kontinentalne Europe, kao i u zemljama BRIICSA ${ }^{\mathrm{I}}$. Nadalje, veća fleksibilnost tržišta rada također može povećati produktivnost u mnogim OECD zemljama, iako autori procjenjuju da su ti učinci slabiji u odnosu na učinke reformi tržišta proizvoda. Prema scenariju u kojem bi se reforme tržišta rada (u područjima sustava naknada za nezaposlenost, aktivnih politika tržišta rada, oporezivanja i mirovinskog sustava) provodile

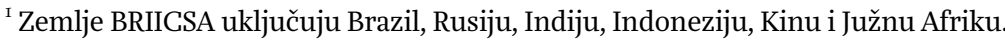


razmjerno brzo, stopa zaposlenosti bi se povećala za nekoliko postotnih poena u OECD zemljama u razdoblju od Io godina. Nadalje, autori procjenjuju da bi se u takvom scenariju zabilježio i porast potencijalnog BDP-a od IO\% u Io godina, što ukazuje na značajan potencijal strukturnih reformi u smislu nadoknade gubitaka uzrokovanih ekonomskom krizom.

Potom, Hobza i Mourre (2010.) istražuju scenarije strategije Europa 2020, s ciljem uviđanja mogućih opsega dobitaka. Rezultati analize ukazuju da napredak u provedbi strukturnih reformi u skladu s glavnim prioritetima u EU-2O2O može generirati značajnu korist u smislu povećanja proizvodnje i stvaranja novih radnih mjesta. Prema autorima, do 2020. godine, BDP može porasti s oko I,5\% do 7\% u odnosu na početne razine, zahvaljujući provedbi politike reformi, što znači između 400 i 2.000 eura dodatnog outputa po osobi. Nadalje, prema ambicioznom scenariju dobici za zapošljavanje bili bi značajni: od oko o,5\% i 4,5\%, što znači stvaranje dodatnih I,6 do gotovo II milijuna radnih mjesta. Istodobno, napredak u strukturnim reformama imao bi pozitivan utjecaj na stopu nezaposlenosti koja bi mogla pasti za između o,5 i 5 postotnih poena.

Everaert i Schule (2008.) na temelju kalibriranog modela ispituju dugoročne dobitke outputa i zaposlenosti od stimuliranja konkurencije na tržištima proizvoda i rada. Autori zaključuju da bi se kombiniranjem reformi proizvoda i tržišta rada mogao izbjeći pad realnih plaća. Nadalje zaključuju da $\mathrm{u}$ kratkom roku, samostalne reforme uzrokuju pad inflacije i rast realne kamatne stope u zemlji koja provodi reforme, zatim usporavanje investicijske reakcije i odgađanje potrošnje. Međutim, usklađivanje reformi bi spriječilo privremeni pad potrošnje, a reforme u monetarnoj uniji omogućuju monetarneoj politici sprječavanje prolaznog pada BDP-a i potrošnje.

Arpaia et al. (2007.), na temelju različitih ekonomskih modela ispituju utjecaj provedenih reformi u razdoblju od 1995. do 2003. u okviru strategije Europske komisije "Growth and Jobs Strategy" u kojoj su tržišta proizvoda i rada bila u središtu reformskog programa. Autori procjenjuju da su reforme $u$ područjima naknada za nezaposlene, poreza i lakoće ulaska novih poduzeća smanjila strukturnu stopu nezaposlenosti za gotovo I,4 postotna poena i povećala BDP u zemljama EU-I5 za 2\% od I995. Pri tome naglašavaju da je pozitivan ishod dijelom rezultat interakcije reformi tržišta proizvoda pri stvaranju novih radnih mjesta (tj. olakšavanje obuzdavanja rasta plaća i ulazak novih tvrtki na tržišta). Autori smatraju da bi ovi rezultati bili još vidljiviji da je u obzir uzet pozitivan utjecaj reformi na stopu participacije.

Možemo zaključiti da opsežna literatura pronalazi pozitivan odnos između strukturnih reformi na području tržišta rada i ekonomskih performansi u dugom roku, dok u kratkom roku, utjecaj reformi može biti malen ili čak negativan zbog troškova prilagodbe. Pritom različiti autori ekonomsku aktivnost aproksimiraju većim brojem pokazatelja poput BDP-a per capita, produktivnosti, stope (ne)zaposlenosti, stope rasta BDP-a, itd. S druge strane, rezultati variraju među autorima s nekoliko aspekata: (I) odabranih pokazatelja reformi, (2) karakteristika korištenih podataka, (3) izbora odgovarajućeg ekonometrijskog modela, (4) veličine i heterogenosti uzorka, te (5) odabira različitih kontrolnih varijabli u modelima. Sve navedeno upozorava na to da se kod interpretacije rezultata zahtijeva određena doza opreza uzimajući u obzir sva potencijalna metodološka ograničenja. 


\section{REFORME TRŽIŠTA RADA U ZEMLJAMA ǦLANICAMA EUROPSKE UNIJE}

S ciljem analize dosadašnjih reformi na tržištu rada koriste se usporedno dvije baze podataka: LABREF baza podataka EU-a u kojoj su sadržane informacije o mjerama politike koje se odnose na institucije na tržištu rada te Fraser Institute baza ekonomskih sloboda u svijetu ${ }^{2}$. Na taj se način kombiniraju dva pristupa mjerenju reformi (vidjeti u Buti et al., 20IO:I2-I3.). Prvi pristup (tzv. ex ante), odnosi se na konstruiranje različitih pokazatelja na temelju stvarnih reformi provedenih u različitim zemljama. Primjer ovog pristupa je upravo LABREF baza podataka, organizirana oko 9 područja politike: oporezivanje, doprinosi nezaposlenima, doprinosi vezani uz blagostanje (npr. socijalna pomoć, sheme za skraćeno radno vrijeme, za bolovanje, itd.), aktivne politike na tržištu rada, zaštita zaposlenja (trajni ugovori, privremeni ugovori i kolektivna otpuštanja), prijevremeno napuštanje tržišta rada (prijevremena mirovina ili invaliditet), određivanje nadnica, radno vrijeme, imigracija i mobilnost. Većinom se na temelju takvih informacija konstruiraju varijable koje pružaju informacije o broju poduzetih akcija (odnosno, reformi) u zemljama. Drugi pristup (tzv. ex post) se sastoji od mjerenja postojećih distorzija povezanih s politikama nositelja vlasti pri čemu se učinak reformi mjeri kao promjena u razini pokazatelja koji mjeri taj stupanj distorzije. Primjer ovakvog pristupa su pokazatelji koje su razvili OECD (Indeks zakonske zaštite zaposlenja, EPL), Fraser Institute (indeks Ekonomske slobode $u$ svijetu), itd. Naime, dok prvi pristup daje uvid u akcije poduzete od strane kreatora politike s ciljem reformiranja postojećih tržišnih ili državnih institucija; drugi pristup ne uzima $u$ obzir navedene akcije već omogućuje analizu učinaka promjena na različite ekonomske ishode.

Na temelju LABREF baze, $u$ grafikonu I. prikazan je ukupan broj reformskih mjera u zemljama članicama EU-a u razdoblju od 200o. do 20II., s ciljem analize vremenskog određenja reformi po skupinama zemalja.

\section{GRAFIKON I.}

Broj provedenih reformskih mjera u zemljama članicama Europske unije, 200o.-20II.

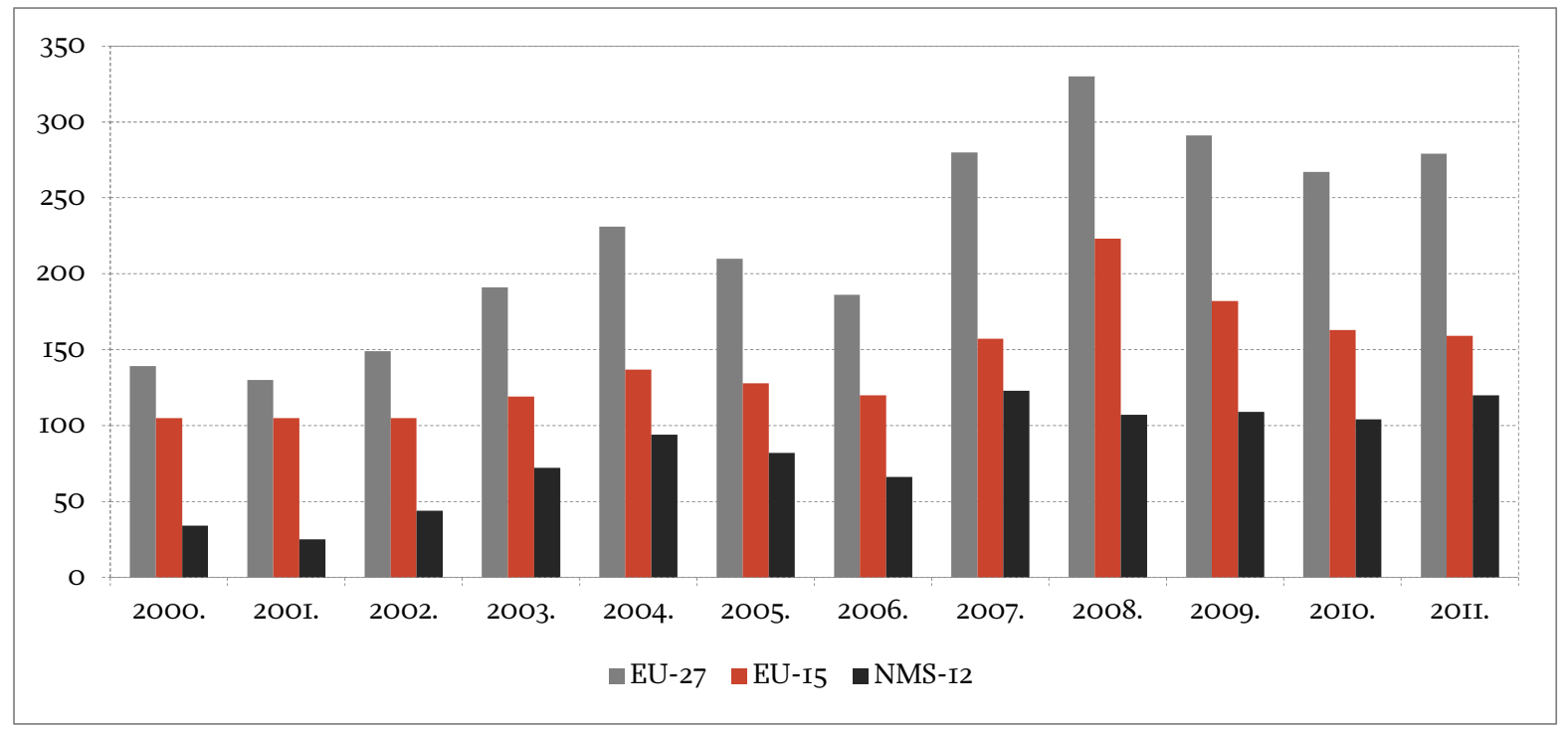

Izvor: izračun autorica prema LABREF bazi podataka (2OI4.).

Na temelju danog grafičkog prikaza može se zaključiti da ukupan broj provedenih reformskih mjera u zemljama članicama EU-27 varira kroz vrijeme. Najmanji broj mjera su zemlje članice EU-27 poduzele

${ }^{2}$ Dostupno na: http://www.freetheworld.com/. 
200I., dok je najveći broj mjera poduzet u 2008., nakon čega dolazi do smanjenja broja reformi uslijed efekata globalne ekonomske krize. Naime, ekonomske krize mogu potaknuti ili usporiti provođenje reformi. Dok s jedne strane pad ekonomske aktivnosti upućuje na to da postojeće politike više nisu održive, s druge strane postoji stajalište da su reforme lakše za implementirati pod povoljnijim makroekonomskim uvjetima budući da su u tom slučaju troškovi provođenja reformi manji i "bezbolniji", a distribucijski efekti manje vidljivi (Drazen i Easterly, 20oı.; Alesina, Ardagna i Trebbi, 2006.; Høj et al., 2006.; MMF, 2004.). Spomenuto potvrđuje i analiza provedena u Turrini et al. (2014.). Naime, autori analiziraju odrednice i utjecaj reformi na tržištu rada u EU u razdoblju od 200o. do 20II. Izvor informacija o provedenim reformama je LABREF baza podataka. Provedena ekonometrijska analiza upućuje na zaključak da zemlje sa sličnim institucionalnim postavkama imaju tendenciju da slijede analogne obrasce reforme, te da je kriza iz 2008. godine potaknula reforme $u$ većini domena tržišta rada u velikom broju zemalja EU-a. Nadalje, reforme su češće kada okruženje karakteriziraju nezadovoljavajući rezultati tržišta rada (osobito visoka i rastuća nezaposlenost) te visoka početna razina propisa ili fiskalnog opterećenja. Ostali makroekonomski i fiskalni čimbenici imaju manje jasnu ulogu.

Ako pogledamo razlike između skupina EU-I5 i NMS-I2 također vidimo određene varijacije. Godine u kojima su nove zemlje članice provele najveći broj reformi su upravo godine proširenja EU-a (2004. i 2007.) iz čega je razvidan snažan međunarodni učinak tijekom procesa ekonomskih integracija na intenzitet reformi. Prema teorijskim postavkama, pritisak na provođenje reformi može doći i od strane raznih obvezujućih pravila kao što je zadovoljavanje kriterija za ulazak u EU, te je utjecaj EU-a posebno važan s aspekta "tvrdih" instrumenata politike (poput Europske monetarne unije) te "mekih" oblika koordinacije kao što su različite strategije koje ukazuju na poželjne promjene na tržištu rada (Tompson i Dang, 20Io.). Također, s aspekta kretanja broja reformi nakon 2008. u NMS-I2, možemo primijetiti da u navedenoj skupini zemalja nije došlo do značajnijeg smanjenja broja reformi te bismo mogli zaključiti da je u ovoj skupini zemalja (u odnosu na EU-I5) kriza bila poticaj provođenju daljnjih reformi tržišta rada.

\section{GRAFIKON 2.}

Broj provedenih reformskih mjera tržišta rada, po zemljama članicama Europske unije, 200o.-20II.

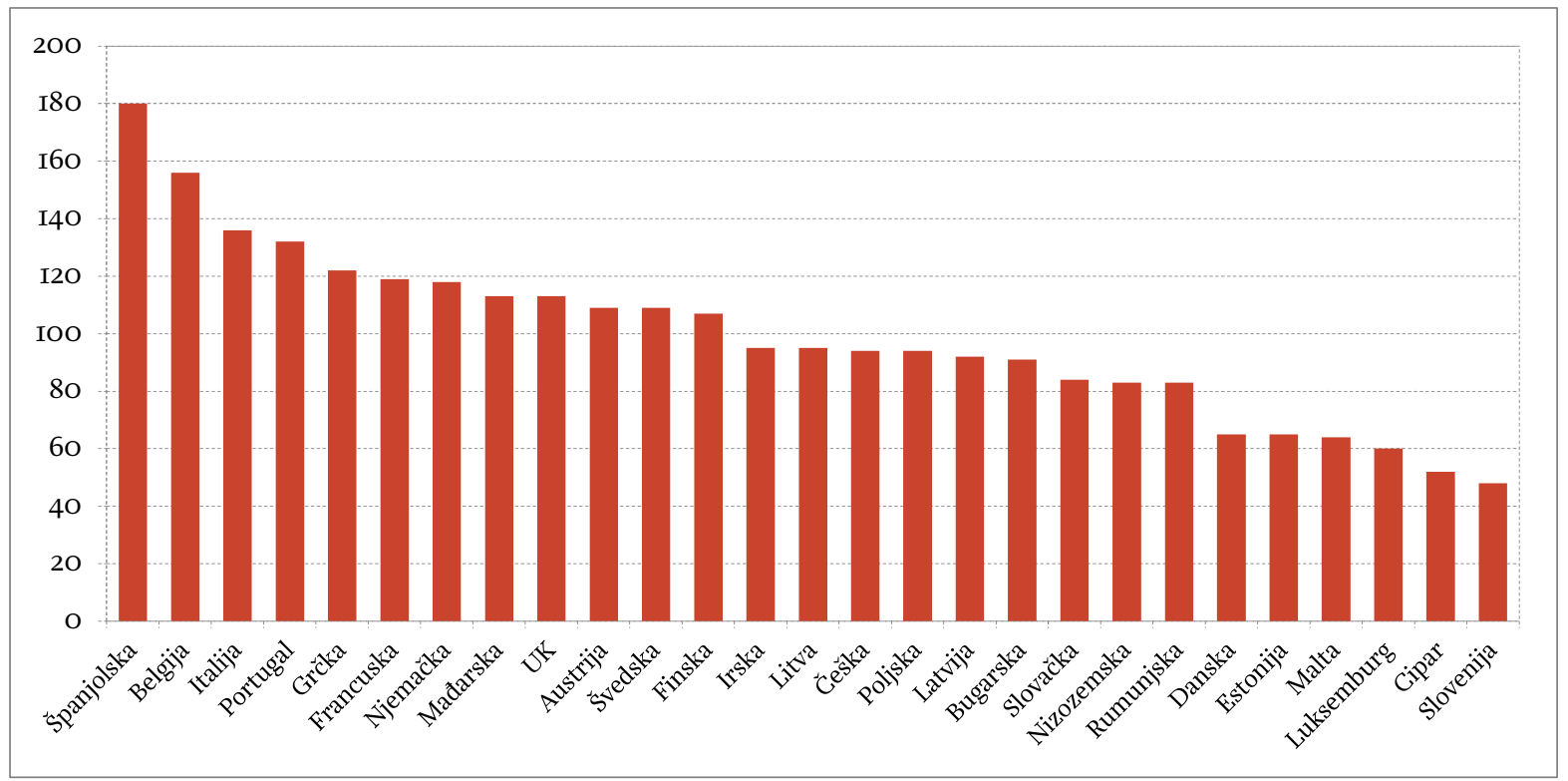

Izvor: izračun autorica prema LABREF bazi podataka (2OI4.). 
Detaljnijom analizom reformskih mjera tržišta rada po pojedinačnim zemljama članicama EU-a (grafikon 2), vidljivo je da su najveći broj mjera u promatranom razdoblju poduzele Španjolska, Belgija, Italija, Portugal i Grčka nasuprot Sloveniji, Cipru i Luksemburgu koje su provele najmanji broj mjera. Nadalje su razvidne razlike između EU-I5 zemalja i I2 novih zemalja članica (NMS-I2) koje su provele gotovo dvostruko manji broj mjera. Podaci za Hrvatsku nisu raspoloživi u okviru LABREF baze za cijeli period od 2000. do 20II. ${ }^{3}$ Iako u ovoj fazi nije uključena u analizu, iskustvo NMS-I2 po pitanju provođenja reformi je bitno za Hrvatsku kao najnoviju članicu EU-a.

Zanimljivo je pogledati i udio pojedinih reformskih mjera iz prethodno navedenih 9 područja politike, u ukupnom broju reformi. Iz grafikona je vidljivo da su zemlje najveći broj reformi provele na području aktivnih politika na tržištu rada i oporezivanja, a najmanji iz područja politika vezanih uz izlazak s tržišta rada.

\section{GRAFIKON 3.}

Reformski profil pojedinih zemalja članica EU-27

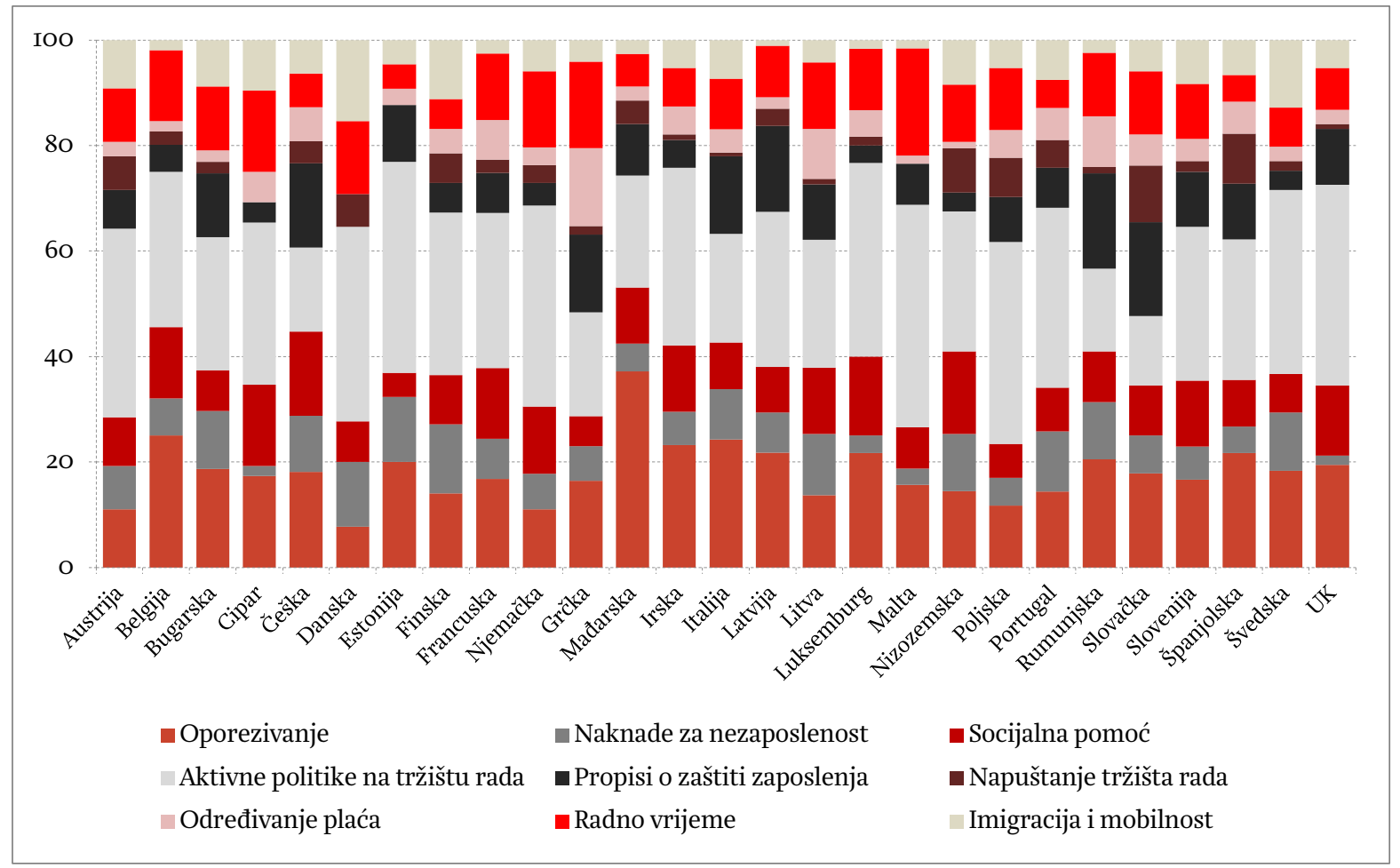

Izvor: izračun autorica prema LABREF bazi podataka (2OI4.).

Budući da reformske mjere sadržane u bazi mogu biti heterogene po pitanju njihovog učinka na institucije na tržištu rada (npr. regulatorni zahtjevi, porezi, doprinosi, itd.), bitno je uzeti u obzir i definiciju smjera reformi koji je također sadržan u bazi za svaku od pojedinačnih domena politike ${ }^{4}$. U tom smislu, reforma ima rastući (padajući) smjer kada dovodi do povećanja (smanjenja) opsega i razine odgovarajućih poreza, povećanja monetarnih koristi ili rigidnosti odgovarajućih regulacija. Nužno je stoga uzeti u obzir i činjenicu da u određenoj godini, u određenoj zemlji, reforme s različitim smjerovima mogu postojati zajedno. Turrini et al. (20I4.) stoga računaju varijablu reform stance kao razliku između reformi s rastućim smjerom i reformi s padajućim smjerom. Na sljedećem grafikonu

${ }^{3}$ Podaci za Hrvatsku su dostupni samo za 20Io. i 20II.

${ }^{4}$ Coverage and structure of the Labour Market Reform (LABREF) Database (20I4.), dostupno na: http://ec.europa.eu/economy_finance/db_indicators/labref/documents/guide_en.pdf. 
prikazan je odnos između broja padajućih i rastućih reformskih mjera, te njihove razlike. Vidljivo je da su u promatranom periodu od 2000. do 20II. zemlje članice EU-a u prosjeku provodile veći broj reformi s rastućim smjerom utjecaja na institucije na tržištu rada.

\section{GRAFIKON 4.}

Broj reformi prema smjeru djelovanja

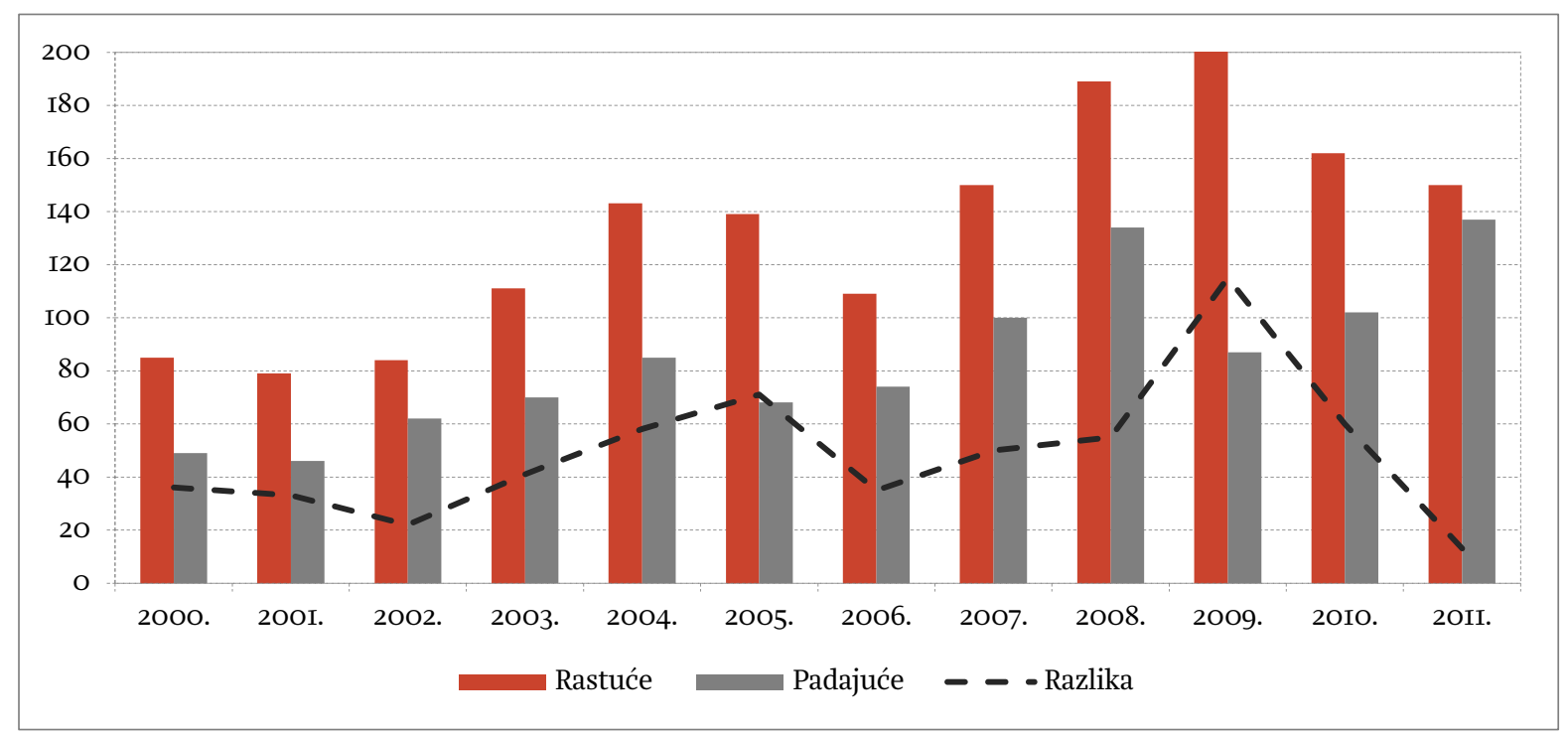

Izvor: izračun autorica prema LABREF bazi podataka (2OI4.).

\section{GRAFIKON 5.}

Ukupan broj reformi i vrijednost indeksa regulacije tržišta rada (EU-27), 2000-20II.

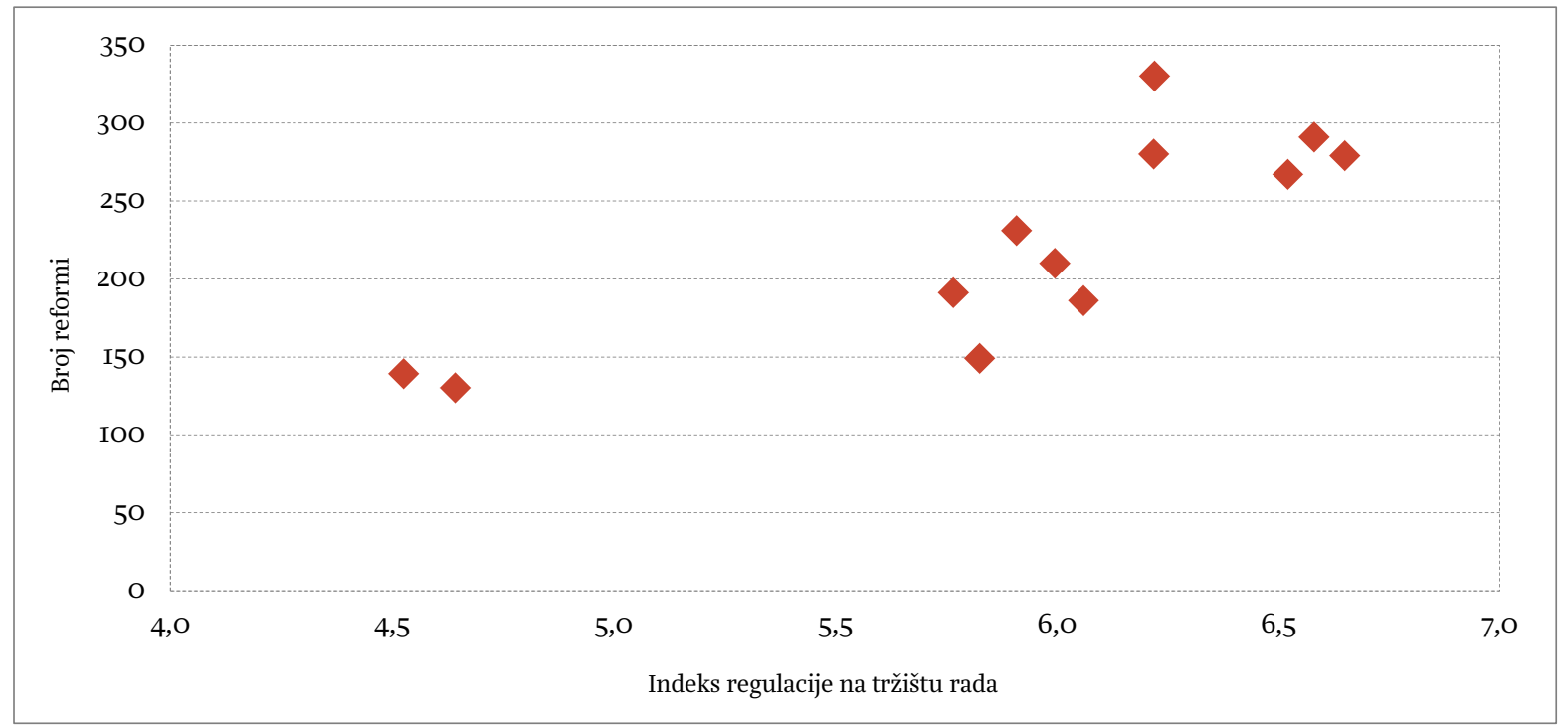

Izvor: izračun autorica prema LABREF bazi podataka (2OI4.).

Dakle, očigledno je da reformska aktivnost varira kako među pojedinim zemljama članicama EU-a tako i kroz vrijeme. Očekuje se stoga da navedene mjere imaju učinak i na "kvalitetu" samog tržišta rada aproksimiranu kompozitnim indeksom propisa tržišta rada (engl. labour market regulations) kojeg na godišnjoj razini objavljuje Fraser Institute u okviru baze ekonomskih sloboda u svijetu . Navedena

\footnotetext{
${ }^{5}$ Baza podataka "Ekonomske slobode u svijetu” pruža opsežne informacije o različitim dimenzijama ekonomske slobode pri čemu se koristi više od četrdeset varijabli s ciljem izračunavanja indeksa kojim se mjeri stupanj ekonomske slobode u pet
} 
baza pruža kompozitnu mjeru fleksibilnosti tržišta rada kao i pokazatelje o fleksibilnosti tržišta rada u šest područja politike: (I) minimalna plaća, (2) reguliranje zapošljavanja i otpuštanja, (3) centralizirani sustav kolektivnog pregovaranja, (4) propisani trošak zapošljavanja, (5) propisani trošak radnog otkaza, i (6) regrutiranje. Indeks poprima vrijednosti u rasponu od nula do deset, pri čemu veći brojevi ukazuju na veću razinu ekonomske slobode na tržištima rada. Stoga se na sljedećem grafikonu prikazuje povezanost između ukupnog broja provedenih reformi u zemljama članicama EU-27 te indeksu regulacije tržišta rada iz Fraser Institute baze (u periodu od 200o.-20II.).

Možemo zaključiti da na razini EU-27, između navedena dva pokazatelja postoji značajna povezanost, na što ukazuje i izračunati koeficijent korelacije koji u ovom slučaju iznosi o,8I ${ }^{6}$. Dakle, očito je da s povećanjem broja reformi dolazi i do povećanja fleksibilnosti na tržištu rada. Međutim, ključno pitanje koje proizlazi iz prethodno provedenog pregleda postojeće literature te deskriptivne analize reformske aktivnosti u zemljama članicama EU-a provedene u ovom poglavlju, je pitanje efikasnosti provedenih reformi sa stajališta ekonomske aktivnosti. Navedeni aspekt se istražuje u nastavku, kroz analizu kratkoročnih i dugoročnih učinaka reformi na tržištu rada (aproksimiranih promjenama u indeksu regulacije na tržištu rada) na BDP po stanovniku.

\section{METOdOLOŠKi OKVIR}

U svrhu procjene dinamičkih i kointegriranih panela najčešce se koriste dvije procedure i to: prosječni procjenitelj grupe (engl. mean group estimator, MG) i tradicionalni združeni (engl. pooled) procjenitelji od kojih svaki ima svoje prednosti i nedostatke (za detalje vidjeti Pesaran i Smith, 1995.).

U ovom će se radu koristiti združeni procjenitelj aritmetičkih sredina grupa (engl. pooled mean group, $P M G$ ), jer obuhvaća združivanje (engl. pooling) nametnuto restrikcijom o homogenosti dugoročnih koeficijenata i uprosječivanje (engl. averaging) kroz grupe, $\mathrm{u}$ svrhu dobivanja aritmetičke sredine procijenjenih koeficijenata ispravljanja pogreške i ostalih kratkoročnih parametara u modelu. Također, ovaj procjenitelj omogućava konstantnim članovima, kratkoročnim koeficijentima i varijancama pogrešaka relacije da se razlikuju po grupama, dok su istovremeno, dugoročni koeficijenti jednaki po grupama.

\section{I. OPIS VARIJABLI}

Model kojim se provodi empirijska analiza učinka reformi na tržištu rada na ekonomsku aktivnost obuhvaća 28 zemalja članica EU-a (uključujući Hrvatsku) što čini polazni panel u analizi. Također, u svrhu usporedbe učinaka reformi na tržištu rada na ekonomsku aktivnost, zemlje članice EU-28 dijele se u dvije skupine (dva sub-panela): EU-I5 i NMS-I3 ${ }^{7}$, jer se temeljem analize reformske aktivnosti provedene u poglavlju 3 pretpostavlja da postoji različit učinak reformi u te dvije skupine zemalja. Analiza obuhvaća dvanaestogodišnje razdoblje, točnije, razdoblje od 2000. do 20II. Naime, godine nakon 2OII. nisu uključene u analizu jer su 20I3. objavljeni posljednji dostupni podaci o fleksibilnosti

područja. To su: veličina države, zakonodavna struktura i vlasnička prava, pristup novcu, sloboda međunarodnog trgovanja te regulacija kredita, rada i poslovanja. Izvještaji se objavljuju od 1996., a polazi se od definicije ekonomske slobode prema kojoj pojedinci posjeduju ekonomsku slobodu kada je imovina koju stječu bez uporabe sile, prijevare ili krađe; fizički zaštićena od drugih pojedinaca, kada se svojom imovinom mogu slobodno koristiti, razmjenjivati je ili davati drugima, uz uvjet da to ne narušava jednaka prava kod drugih osoba (Gwartney, Lawson i Block, 1996.).

${ }^{6}$ Koeficijent korelacije između ova dva pokazatelja je za NMS-ı2 još i veći, te iznosi o,go.

${ }^{7}$ Preciznije, pod novim zemljama članicama podrazumijevaju se članice koje su EU pristupile I. svibnja 20o4. (Cipar, Češka, Estonija, Latvija, Litva, Mađarska, Poljska, Slovačka, Slovenija i Malta), potom I. siječnja 2007. (Bugarska i Rumunjska), te Hrvatska koja je EU pristupila I. srpnja 20I3. Skupinu EU-I5 čine Austrija, Belgija, Danska, Finska, Francuska, Njemačka, Grčka, Irska, Italija, Luksemburg, Nizozemska, Portugal, Španjolska, Švedska i Ujedinjeno Kraljevstvo. 
tržišta rada, a odnose se na 2OII., čime su isključeni utjecaji mjera donesenih u posljednje dvije godine. Dakle, reforme tržišta rada su aproksimirane kompozitnim indeksom propisa tržišta rada (engl. labour market regulations) Fraser Instituta ${ }^{8}$. Navedeni indeks suočen je s istim nedostacima koji se pripisuju kompozitnim indeksima općenito (za detalje vidjeti OECD, 2008.). Svjesni svih nedostataka ${ }^{9}$ indeksa u pitanju, ističemo nekoliko prednosti. Prvo, prednost pristupa korištenog u ovom radu ogleda se upravo u primjeni agregatnog indeksa. Naime, vlada je potencijalno pod utjecajem cijele serije političkih akcija, a promjene $u$ jednom od područja često su korelirane s promjenama $u$ drugim područjima politike (prema Buti et al., 20Io.). Dakle, ključna prednost agregiranog pred korištenjem pojedinačnih pokazatelja i metoda kojima se procjenjuje učinak različitih reformi na ekonomske ishode, je $\mathrm{u}$ tome što uključivanje pojedinačnih pokazatelja može rezultirati problemima koji proizlaze iz pridavanja učinka isključenih ili neopaženih akcija onima koje su uključene u analizu. Nadalje, u vezi kritika usmjerenih na to da indeks ne sadrži stvarne reformske procese, $u$ okviru poglavlja 3 je pokazano da na uzorku zemalja EU-a postoji pozitivna veza između broja provedenih reformi s jedne, te vrijednosti Fraser indeksa s druge strane, na temelju čega je i pristupljeno ovakvoj analizi. Konačno, kritike su usmjerene i općenito prema korištenju indeksa kreiranih od strane organizacija koje su pristrane prema politikama slobodnog tržišta (primjer je i ovaj indeks) (Chang, 20II.). Međutim, u ovom radu autori ne iznose vrijednosne sudove po pitanju poželjnog stupnja fleksibilnosti i sloboda na tržištu rada, već je istraživački fokus usmjeren na ex post analizu učinka dosadašnjih promjena na ekonomsku aktivnost. U skladu s ekonomskom literaturom, očekuje se da će reforme koje povećavaju ekonomske slobode i fleksibilnost na tržištu rada imati pozitivni učinak na ekonomsku aktivnost u dugom, a negativni u kratkom roku.

U modelu je provedena dinamička panel analiza u kojoj će zavisna varijabla biti BDP po stanovniku. Naime, strukturne reforme doprinose potencijalu rasta, stvarajući uvjete za održiv i uravnotežen rast, što dovodi do poboljšanja na području zapošljavanja i životnog standarda (European Commission, 20I4.). Nezavisne varijable uključene u model su, osim indeksa propisa tržišta rada, dummy varijabla za ekonomsku krizu, industrijska proizvodnja i udio aktivnog stanovništva u ukupnoj populaciji. Pritom je dummy varijabla ekonomske krize definirana na način da poprima vrijednost I kada je vrijednost jaza ouputa -4\% BDP-a ili više (prema Duval i Elmeskov, 2006.; Høj et al., 2006.). Nadalje, dinamični proizvodni sektor ponovno se smatra preduvjetom za inovativne i brzo-rastuće ekonomije (European Commission, 20I3.), što ga čini važnom odrednicom ekonomske aktivnosti. O spomenutom svjedoči i novi pristup Europske komisije industrijskoj politici temeljem kojeg Komisija nastoji obrnuti opadajuću ulogu industrije u Europi, s razine od oko I6\% BDP-a (u 20I2.) na čak 20 \% do 2020. Dodatno, industrija čini više od $80 \%$ europskog izvoza, privatnog istraživanja i inovacija. Štoviše, gotovo jedno od četiri radna mjesta $u$ privatnom sektoru, nalazi se $u$ industriji (European Commission, 2013.). Stoga se empirijskom analizom također istražuje u kojoj mjeri makroekonomski uvjeti oblikuju kratkoročni i dugoročni utjecaj reformi na ekonomski rast. To je učinjeno uvođenjem

\footnotetext{
${ }^{8} \mathrm{~S}$ aspekta ekonomskih sloboda, postoji i baza "Indeks ekonomskih sloboda” (Heritage Foundation: http://www.heritage.org/index/book/chapter-7) prema kojoj se ekonomska sloboda promatra kao stanje u kojem pojedinci mogu djelovati autonomno, a u ekonomski slobodnom društvu, donošenje odluka od strane vlada je transparentno te se garantiraju jednake mogućnosti za sve. Međutim, cilj ekonomske slobode nije samo odsustvo državne prisile ili ograničenja, već stvaranje i održavanje zajedničkog osjećaja slobode za sve pri čemu pojedinci imaju obvezu poštivati ekonomska prava i slobode drugih u okvirima vladavine prava. Zapravo, radi se o konceptu koji je širi od koncepta poslovnog okruženja, ali daje koristan uvid u perspektivu poslovnog okruženja zemalja. Ovaj indeks obuhvaća deset specifičnih komponenti ekonomskih sloboda: slobodu poslovanja, trgovinsku slobodu, fiskalnu slobodu, državnu potrošnju, monetarnu slobodu, slobodu investiranja, financijsku slobodu, zaštitu vlasničkih prava, slobodu od korupcije te slobodu na tržištu rada. Međutim, ova je baza, ograničena s aspekta dostupnosti duže serije podataka iz komponente sloboda na tržištu rada.

${ }_{9}^{9}$ Detaljan pregled kritika na upotrebu ovog indeksa može se pronaći kod Aleksynska (20I4.).
} 
pokazatelja industrijske proizvodnje koja, uz stopu aktivnosti (izraženu kao udio aktivnog stanovništva (I5-64) u populaciji u dobi I5-64) služi i kao kontrolna varijabla u modelu. Varijable BDP po stanovniku i industrijska proizvodnja su izražene u logaritmima, dok je stopa aktivnosti izražena u postocima. Izvori korištenih podataka i očekivani predznaci dani su prilogu, tablica AI.

\subsection{ODABIR MODELA}

Empirijska analiza počinje od slijedeće jednadžbe:

$$
\begin{gathered}
B D P_{-} p c_{i t}=\gamma_{0 i}+\gamma_{1 i} \text { ind }- \text { pro }_{i t}+\gamma_{2 i} l m_{-} r e g_{i t}+\gamma_{3 i} a c t_{-} r_{i t}+\text { crisis }+\varepsilon_{i t}, \\
i=1,2, \ldots, N, t=1,2, \ldots, T_{i}
\end{gathered}
$$

pri čemu je: $B D P \_p c_{i t}$ logaritam bruto domaćeg proizvoda po stanovniku, ind_pro ${ }_{i t}$ logaritam indeksa industrijske proizvodnje; $l m \_r e g_{i t}$ indeks regulacije tržišta rada, $a c t \_r$ je stopa aktivnosti, dok je crisis binarna (dummy) varijabla ekonomske krize. Indeksi $i$ i $t$ označavaju zemlju i vremenski period ${ }^{\text {Io }}$. Greška relacije $\left(\varepsilon_{i t}\right)$ se odnosi na učinke nepredvidivih šokova u ekonomskoj aktivnosti aproksimiranoj bruto domaćim proizvodom po stanovniku.

Koeficijenti $\gamma_{\mathrm{I}}, \gamma_{2 i} \mathrm{i} \gamma_{3 i}$ predstavljaju učinke permanentnih promjena na BDP po stanovniku, održivih u dugome roku, koji imaju svojstvo elastičnosti. Odstupanja od dugoročne povezanosti dane jednadžbom (I) moguća su u kratkom roku. Naime, postoje različiti razlozi za takva odstupanja koji onemogućavaju trenutnu prilagodbu BDP per capita na promjenu u njegovim determinantama i zato ih se mora uzeti u obzir prilikom empirijske analize.

U skladu s tim, ekonometrijska specifikacija u ovom radu dozvoljava različit utjecaj odabranih nezavisnih varijabli na BDP po stanovniku po zemljama, što je formalno implementirano u model određivanjem duljine pomaka za svaku varijablu prema standardnim statističkim kriterijima. Nakon određivanja broja pomaka pomoću SBC kriterija ${ }^{\text {II }}$ (engl. Schwarz Bayesian Criterion) za svaku varijablu pojedinačno ${ }^{\mathrm{I2}}$, panel ARDL(I,O,O,O) model, pokazao se adekvatnim za analizu i dan je jednadžbom (2):

$$
B D P_{-} p c_{i t}=\delta_{i}+\beta_{10 i} \text { ind } \text { pro }_{i t}+\beta_{20 i} l m_{-} r e g_{i t}+\beta_{30 i} a c t_{-} r_{i t}+\gamma_{i} B D P P_{-} p c_{i, t-1}+c r i s i s+\eta_{i t}
$$

Budući da su Pesaran i Shin (1995.) pokazali da pristup modeliranju korištenjem ARDL modela nije opravdan ukoliko varijable u jednadžbi (2) nisu integrirane prvog reda, reparametrizacijom jednadžbe (2) dobiva se jednadžba (3) u obliku panel modela ispravljanja pogreške (engl. panel error correction model), odnosno:

$$
\begin{aligned}
& \Delta B D P_{-} p c_{i t}=\phi_{i}\left(B D P_{-} p c_{i, t-1}-\gamma_{0 i}-\gamma_{1 i} i n d_{-} p r o_{i t}-\gamma_{2 i} l m_{-} r e g_{i t}-\gamma_{3 i} a c t_{-} r_{i t}-c r i s i s\right)- \\
& -\beta_{11 i} \Delta i n d_{-} \operatorname{pro}_{i t}-\beta_{21 i} \Delta l m_{-} r e g_{i t}-\beta_{31 i} \Delta a c t_{-} r_{i t}+\eta_{i t}
\end{aligned}
$$

Pri čemu je $\Delta$ operator prvih diferencija i vrijedi:

$$
\phi_{i}=-\left(1-\gamma_{i}\right), \gamma_{0 i}=\frac{\delta_{i}}{1-\gamma_{i}}, \gamma_{1 i}=\frac{\beta_{10 i}+\beta_{11 i}}{1-\gamma_{i}}, \gamma_{2 i}=\frac{\beta_{20 i}+\beta_{21 i}}{1-\gamma_{i}}, \gamma_{3 i}=\frac{\beta_{30 i}+\beta_{31 i}}{1-\gamma_{i}},
$$

\footnotetext{
${ }^{\text {Io }}$ Budući da T ima indeks $i$, radi se o nebalansiranom panelu.

${ }^{\text {II }}$ Schwartz-Bayesov kriterij (SBC) je kriterij odabira modela koji se temelji na principu parsimonije. Smatra se najrigoroznijim kriterijem, jer odabire modele s najmanjim brojem parametara. Definira se formulom: $S B C=-2 \cdot \ln (L)+M \ln (T)$, pri čemu je $L$ oznaka za maksimum funkcije vjerodostojnosti, $M$ je ukupan broj procijenjenih parametara ARMA $(p, q)$ modela, a T je broj podataka koji se koristi u procjeni i ne mora biti jednak duljini niza $n$ (detaljnije vidjeti u: Bahovec i Erjavec, 2009.).

${ }^{\mathrm{I} 2}$ Rezultati analize u kojoj se odabire odgovarajući broj pomaka za svaku varijablu pojedinačno, ovdje se izostavljaju, ali su dostupni od autora na zahtjev.
} 
Budući da prema Engle i Granger (1987.) teoremu postoji jasna povezanost između kointegracijskog mehanizma i mehanizma ispravljanja pogreške, jednadžba (3) predstavlja temelj za procjenu dugoročne povezanosti između ekonomske aktivnosti (BDP-a po stanovniku) s jedne strane i odabranog skupa nezavisnih varijabli, s druge strane.

Unutar definiranog okvira, Pesaran, Shin i Smith (1999.) sugeriraju da koeficijenti dugoročne povezanosti u jednadžbi (3) budu jednaki kroz zemlje (tzv. dugoročna homogenost) dok konstantni članovi, brzina prilagodbe, kratkoročni koeficijenti i varijance pogrešaka mogu varirati po zemljama ${ }^{\mathrm{I}}$.

Također, pod pretpostavkom homogenosti nagiba, združeni procjenitelj aritmetičkih sredina grupa, PMG, je konzistentan i efikasan, dok je MG procjenitelj konzistentan, ali nije efikasan, stoga se za usporedbu ova dva procjenitelja može iskoristiti test Hausmannovog tipa (Pesaran, Shin i Smith, 1999.), koji se u empirijskoj analizi i provodi. Nadalje, u svrhu provjere robusnosti rezultata analize, panel EU-28 se dijeli na dva sub-panela: panel EU-I5 i panel novih zemalja članica (NMS-I3), a koristi se i dinamički procjenitelj fiksnih efekata (engl. dynamic fixed effects estimator, DFE) kako bi se dodatno provjerila robusnost rezultata provedene empirijske analize.

\section{REZULTATI EMPIRIJSKE ANALIZE}

Kao početni korak u empirijskoj analizi provedeni su panel testovi jediničnih korijena, rezultati kojih su dani u prilogu, tablica A2. Budući da su prema rezultatima provedenih testova sve varijable od interesa integrirane prvog reda, sljedeći je korak $u$ analizi testiranje postojanja ravnotežne kointegrirajuće povezanosti među njima, pri čemu se koriste četiri nova panel testa kointegracije koje je razvio Westerlund (2007.) ${ }^{\mathrm{I}}$. Prema rezultatima panel testova kointegracije (prilog, tablica A3) razvidno je da postoji kointegrirajuća povezanost između analiziranih varijabli.

Budući da su varijable od interesa nestacionarne i kointegrirane, procjena jednadžbe (3) pomoću odabranog PMG procjenitelja omogućuje pouzdanu inferenciju o dugoročnom i kratkoročnom učinku reformi tržišta rada na ekonomsku aktivnost (BDP po stanovniku). U prilogu, tablica A4. dani su rezultati provedene empirijske analize ${ }^{\mathrm{I} 5}$ i Hausmanovog specifikacijskog testa, zajedno $\mathrm{s}$ odgovarajućim standardnim pogreškama procjene (danim u uglatim zagradama) za cijeli panel EU$28 .^{16}$

Rezultati Hausmanovog testa ukazuju da je prikladno koristiti PMG procjenitelj ${ }^{\mathrm{I7}}$ i model je pravilno specificiran, pa se može pristupiti interpretaciji dobivenih procjena parametara.

Dugoročni koeficijent regulacije tržišta rada je statistički signifikantan na razini signifikantnosti I\%, sugerirajući da je elastičnost BDP-a po stanovniku na promjene u regulaciji tržišta rada o,25I. Nadalje, industrijska proizvodnja i stopa aktivnosti stanovništva, također su statistički značajne na I\%, sugerirajući elastičnost BDP-a po stanovniku na promjene u navedenim varijablama od I,29o, odnosno o,o22. Binarna (dummy) varijabla ekonomska kriza u dugom roku značajno utječe na BDP po

\footnotetext{
${ }^{13}$ Drugim riječima, nameće se $(\mathrm{N}-\mathrm{I}) * k$ restrikcija na model dan izrazom (4) i to oblika: $\gamma_{i=} \gamma$ za svaki $i$. Procjenitelj temeljen na metodi najveće vjerodostojnosti (engl. maximum likelihood, ML) naziva se PMG procjenitelj i ima asimptotski normalnu distribuciju u slučaju stacionarnih i nestacionarnih regresora.

${ }^{\text {I4 }}$ Ovi su testovi temeljeni na strukturnoj dinamici, a ne na dinamici reziduala, pa u tom smislu ne nameću restrikciju o postojanju zajedničkih faktora (engl. common-factor restriction). Dva su testa dizajnirana tako da testiraju alternativnu hipotezu o kointegriranosti panela kao cjeline $\left(P_{\alpha} i P_{\tau}\right)$, dok preostala dva testa testiraju alternativnu hipotezu da je barem jedna jedinica $u$ panelu kointegrirana, $\left(G_{\alpha} \mathrm{i} G_{\tau}\right)$, (Persyn i Westerlund, 2008.).

${ }^{15}$ Rezultati se odnose na procjene dugoročnih parametara i prosječne procjene kratkoročnih parametara.

${ }^{16}$ Procjena modela je provedena u statističkom softveru STATA I2.

${ }^{17}$ Budući da on dopušta heterogenost parametara $u$ kratkom roku.
} 
stanovniku s koeficijentiom elastičnosti -0,58I. Nadalje, faktor korekcije pogreške ${ }^{\mathrm{I} 8}$ iznosi -o,357 ima odgovarajući negativni predznak i statistički je signifikantan na razini signifikantnosti ı\%, pa se može zaključiti da se dugoročno ravnotežno stanje dano s kointegrirajućom relacijom između ekonomske aktivnosti i odabranog skupa nezavisnih varijabli dostiže za nešto manje od 3 godine. Također, BDP po stanovniku se prilagođava svojoj dugoročnoj ravnoteži s pomacima.

U kratkom roku, reforma tržišta rada ima očekivani negativni predznak i statistički je značajna na razini značajnosti IO\% s koeficijentom elastičnosti od -o,o375. Ostale varijable nemaju statistički značajan utjecaj na ekonomsku aktivnost u kratkom roku.

U nastavku analize model dan jednadžbom (4) procjenjuje se za dva sub-panela, točnije za panel starih zemalja članica (EU-I5) i panel novih zemalja članica (NMS-I3), kako bi se utvrdio utjecaj reformi tržišta rada na ekonomsku aktivnost u navedenim skupinama zemalja. Rezultati analize dani su u prilogu, tablica A5. Na temelju prikazanih rezultata nameće se zaključak da u obje skupine zemalja u dugom roku postoji statistički značajan utjecaj reformi tržišta rada na ekonomsku aktivnost i to na razini signifikantnosti od I\%. Također, razvidno je i da u slučaju panela EU-I5 koeficijent elastičnosti ekonomske aktivnosti na promjene u reformama tržišta rada iznosi o,29I, sugerirajući veći relativni utjecaj reformi tržišta rada na ekonomsku aktivnost u starim zemljama članicama (EU-I5) u odnosu na nove zemlje članice (NMS-13) u slučaju kojih je koeficijent znatno manji i iznosi o,o74. Zanimljivo je, međutim, i da je utjecaj krize na ekonomsku aktivnost u dugom roku izraženiji u slučaju novih zemalja članica (u usporedbi s EU-I5) sa statistički značajnim i negativnim koeficijentom od -0,523 (u slučaju EU-I5 taj koeficijent iznosi -0,362). Nasuprot tome, $u$ dugom roku industrijska proizvodnja i stopa aktivnosti stanovništava u NMS-I3 značajnije utječu na ekonomsku aktivnost nego li u EU-15, s koeficijentima od I,720 i o,044 (u usporedbi s koeficijentima za EU-I5 od I,338 i o,032).

Nadalje, faktor korekcije pogreške u slučaju starih zemalja članica iznosi -o,295, dok isti u slučaju novih zemalja članica iznosi -0,442. Oba koeficijenta imaju odgovarajući negativni predznak i statistički su signifikantni na razini signifikantnosti I\%. Međutim, sugeriraju da se dugoročno ravnotežno stanje dano s kointegrirajućom relacijom između BDP-a po stanovniku, industrijske proizvodnje, regulacije tržišta, te stope aktivnosti stanovništva, u novim zemljama članicama dostiže nešto brže nego u starim zemljama članicama. Također, reforme tržišta rada u kratkom roku imaju statistički značajan koeficijent samo u slučaju starih zemalja članica. Ostale varijable nemaju statistički značajan utjecaj na ekonomsku aktivnost u kratkom roku.

Kako bi se dodatno provjerila robusnost procijenjenih modela, korišten je (uz PMG) i DFE procjenitelj (engl. dynamic fixed effects estimator), koji pretpostavlja da su koeficijenti kointegrirajućeg vektora jednaki u svim zemljama u panelu, te da su i kratkoročni koeficijenti i brzina prilagodbe jednaki po zemljama, a samo konstantni članovi mogu varirati po zemljama. Rezultati procjene cijelog panela (EU-28), te sub-panela dani su u prilogu, tablica A6. Prema rezultatima procijenjenog DFE modela, razvidno je da u slučaju sva tri panela postoji statistički značajan dugoročni utjecaj reformi tržišta rada na ekonomsku aktivnost, što potvrđuje rezultate dobivene pomoću PMG procjenitelja. Jedino

\footnotetext{
${ }^{18}$ Faktor korekcije pogreške dan u prilogu, tablica A4. izračunata je kao neponderirana (jednostavna) aritmetička sredina odgovarajućih faktora korekcije pogreške za 28 zemalja u panelu (koji su heterogeni prema PMG proceduri).

${ }^{19}$ Faktor korekcije pogreške ili brzina prilagodbe ravnotežnom stanju $(\phi)$ je u modelu statistički značajan parametar i ima očekivanu negativnu vrijednost jer se očekuje (a procijenjeni model to i dokazuje) da se odstupanja između ekonomske aktivnosti i odabranog skupa nezavisnih varijabli od njihove dugoročne ravnotežne povezanosti postupno smanjuju. Budući da su u radu korišteni godišnji podaci, ravnoteža u dugom roku (ekvilibrij) će se dostići za nešto manje od 3 godine (detaljnije o modelu korekcije pogreške vidjeti u: Bahovec i Erjavec, 2009.).
} 
odstupanje u rezultatima vidljivo je kod varijable industrijske proizvodnje. Naime, kratkoročni koeficijenti za industrijsku proizvodnju statistički su značajni, ali s različitim predznakom za poduzorke. Spomenuto se može objasniti činjenicom da je proizvodnja posljednjih godina pretrpjela velike gubitke, uzrokovane dugotrajnom ekonomskom krizom, koji u pojedinim granama mogu voditi trajnom gubitku proizvodnih kapaciteta, osobito u novim zemljama članicama. Ostali rezultati prikazani su u prilogu, tablica A6, te potvrđuju robusnost baznog modela ${ }^{20}$.

\section{ZAKLJUČAK}

Globalna ekonomska kriza je promijenila percepciju uloge strukturnih reformi u gospodarstvu što je posebno istaknuto na razini EU-a s obzirom da su tradicionalne mjere za kreiranje ekonomskih politika "potrošene". Dakle, trenutna kriza predstavlja veliki izazov po pitanju provođenja strukturnih reformi, i to ne samo za zemlje EU-a. Jedan od takvih izazova je i reforma tržišta rada koja se zbog svoje kompleksnosti, te posebno troškova koje izaziva u kratkom roku, često odgađa.

Prema dobivenim empirijskim rezultatima, reforme tržišta rada koje povećavaju fleksibilnost i ekonomske slobode u dugom roku značajno utječu na BDP po stanovniku u EU-28 zemljama, a imaju i statistički signifikantan pozitivan predznak u zemljama EU-I5 i u I3 novih zemalja članica EU-a. Međutim, kratkoročno, reforme također imaju statistički značajan, ali negativan utjecaj na BDP po stanovniku u zemljama EU-27 te skupini EU-I5 zemalja, dok u novim zemljama članicama kratkoročni utjecaj nije statistički značajan (što se može objasniti time što su navedene zemlje i kasnije krenule s intenzivnijom reformskom aktivnošću). Zaključuje se stoga da su rezultati dobiveni u ovom radu konzistentni s ekonomskom teorijom te dosadašnjim provedenim istraživanjima (primjerice Banes et al., 2013.; Cacciatore, Duval i Fiori, 2012.) koja ističu da se koristi reformi na tržištu rada vide tek dugoročno, a koji su opisani i u ovome radu.

I4 Zaključno, pošto su jedne od "bolnijih" reformi, reforme tržišta rada trebaju biti odgovornost svih ključnih igrača: vlade, poslovne zajednice, zaposlenih i sindikata. Naime, kao i svaka reforma, reforma tržišta rada rezultira dobitnicima (dugoročno) i gubitnicima (kratkoročno) te nositelji vlasti ponekad nisu ni svjesni raširenosti otpora prema reformama koji u većini slučajeva nastaje kao posljedica nerazumijevanja zašto se neka reforma treba provesti. Upravo pitanje na koji način osigurati političku podršku za provođenje reformi, uzimajući u obzir dobivene rezultate provedene ekonometrijske analize u ovom radu, vidimo kao jedan od putova za buduća istraživanja ovog kompleksnog područja.

\footnotetext{
${ }^{20}$ DFE (engl. dynamic fixed effects estimator) dinamički procjenitelj fiksnih efekata, kao i PMG (združeni procjenitelj aritmetičkih sredina grupa), nameće restrikciju jednakosti koeficijenata kointegrirajućeg vektora za sve grupe (zemlje). Međutim, prema DFE procjenitelju, brzina prilagodbe i kratkoročni koeficijenti, također su jednaki za sve grupe. Budući da prema restriktivnom DFE procjenitelju svi koeficijenti modela imaju odgovarajući predznak i da su slični po vrijednostima procijenjenim koeficijentima PMG modela za sve skupine zemalja, nameće se zaključak da je procijenjeni model prema PMG procjenitelju robustan (više o svojstvima procjenitelja MG, PMG i DFE pogledati u: Blackburne i Frank, 2007.).
} 
Prilozi

Tablica Ai.

Izvori podataka i očekivani predznaci

\begin{tabular}{|c|c|c|c|}
\hline Varijabla & Opis varijable & Izvor podataka & Očekivani predznak \\
\hline $\mathrm{BDP} p c$ & BDP po stanovniku (tekuće cijene) & World Economic Outlook & Pozitivan \\
\hline Lm_reg & $\begin{array}{l}\text { Proxy varijabla za reformu tržišta rada } \\
\text { (regulacija tržišta rada) }\end{array}$ & $\begin{array}{l}\text { Economic Freedom of the } \\
\text { World (Fraser Institute) }\end{array}$ & $\begin{array}{l}\text { U kratkom roku negativan, } \\
\text { u dugom roku pozitivan }\end{array}$ \\
\hline Kriza & $\begin{array}{l}\text { Dummy varijabla ekonomske krize (jaz } \\
\text { između stvarnog i potencijalnog BDP-a) }\end{array}$ & AMECO & Negativan \\
\hline Ind_pro & $\begin{array}{l}\text { Industrijska proizvodnja (indeks } \\
\text { industrijske proizvodnje; prerađivačka } \\
\text { industrija) }\end{array}$ & Eurostat & Pozitivan \\
\hline Act_r & Stopa aktivnosti (15-64) & Eurostat & Pozitivan \\
\hline
\end{tabular}

Izvor: izračun autorica.

\section{TAblica A2.}

Rezultati panel testova jediničnih korijena

\begin{tabular}{|c|c|c|c|c|}
\hline Varijable & & Metoda & Prob.* & Obs. \\
\hline \multirow{4}{*}{$B D P_{-} p c_{i t}$} & \multirow{4}{*}{ Konstanta i trend } & Levin, Lin \& Chu t & 0.000 & 280 \\
\hline & & Im. Pesaran and Shin W-stat & 0.7383 & 280 \\
\hline & & ADF-Fisher Chi-square & 0.9732 & 280 \\
\hline & & PP-Fisher Chi-square & 0.9977 & 308 \\
\hline \multirow{4}{*}{ lm_reg ${ }_{i t}$} & \multirow{4}{*}{ Konstanta i trend } & Levin, Lin \& Chu t & I.0000 & 298 \\
\hline & & Im. Pesaran and Shin W-stat & I.OOOO & 298 \\
\hline & & ADF-Fisher Chi-square & I.OOOO & 298 \\
\hline & & PP-Fisher Chi-square & I.OOOO & 300 \\
\hline \multirow{4}{*}{ Ind_pro $_{\text {it }}$} & \multirow{4}{*}{ Konstanta i trend } & Levin, Lin \& Chu t & 0.0000 & 299 \\
\hline & & Im. Pesaran and Shin W-stat & 0.8610 & 299 \\
\hline & & ADF-Fisher Chi-square & $0.905 \mathrm{I}$ & 299 \\
\hline & & PP-Fisher Chi-square & 0.9302 & 308 \\
\hline \multirow{4}{*}{ act_r $r_{i t}$} & \multirow{4}{*}{ Konstanta i trend } & Levin, Lin \& Chu t & 0.0000 & 267 \\
\hline & & Im. Pesaran and Shin W-stat & 0.3089 & 267 \\
\hline & & ADF-Fisher Chi-square & 0.1383 & 267 \\
\hline & & PP-Fisher Chi-square & 0.8899 & 278 \\
\hline
\end{tabular}

* p-vrijednosti za Fisherove testove izračunate su pomoću asimptotske Hi-kvadrat distribucije. Svi drugi testovi pretpostavljaju asimptotsku normalnost. Im, Pesaran Shin, ADF-Fisher i PP-fisher test-nulta hipoteza: jedinični korijen (pojedinačni proces jediničnog korijena), Levin, Lin Chu test-nulta hipoteza: jedinični korijen (zajednički proces jediničnog korijena). Broj pomaka određen je korištenjem SBC kriterija.

Izvor: izračun autorica. 
TABLica A3.

Rezultati panel testova kointegracije

Test

Nulta hipoteza

Alternativna hipoteza

Test veličina

p-vrijednost

Westerlund $\quad$ Nema kointegracije $\quad \begin{aligned} & \text { Paneli su kointegrirani } \\ & \text { kao cjelina } \\ & \text { Barem jedna jedinica } \\ & \text { u panelu je kointegrirana }\end{aligned}$

Izvor: izračun autorica.

\section{TABLIGA A4.}

PMG procjene utjecaja reformi tržišta rada na BDP per capita za panel EU-28 Varijabla

Panel EU-28

Dugoročni koeficijenti

$\begin{array}{lr}\text { Im_reg } & \begin{array}{r}0,25 \mathrm{I}^{* * *} \\ {[\mathrm{O}, \mathrm{OI}]}\end{array} \\ \text { crisis } & -\mathrm{O}, 58 \mathrm{I}^{* * *} \\ {[\mathrm{O}, \mathrm{II} 4]}\end{array}$

Kratkoročni koeficijenti

Faktor korekcije pogreške

$-0,357^{* *}$

[0,054]

\begin{tabular}{|c|c|}
\hline$\Delta \mathrm{Ind} \_p r o$ & $\begin{array}{l}-0,336 \\
{[0,421]}\end{array}$ \\
\hline$\Delta l m \_r e g$ & $\begin{array}{c}-\mathrm{O}, \mathrm{O} 375^{*} \\
{[\mathrm{O}, \mathrm{O} 2 \mathrm{I}]}\end{array}$ \\
\hline$\Delta a c t \_r$ & $\begin{array}{c}\mathrm{O}, \mathrm{O} 28 \\
{[\mathrm{O}, \mathrm{O} 9 \mathrm{I}]}\end{array}$ \\
\hline konstanta & $\begin{array}{c}-\mathrm{I}, 553^{* *} \\
{[0,247]}\end{array}$ \\
\hline
\end{tabular}

Hausmanov specifikacijski test

vrijednost

$0,5 \mathrm{I}$

$(0,97)^{a}$

${ }^{a}$ Vrijednost u zagradi odnosi se na empirijsku razinu signifikantnosti (p-vrijednost) i označava da na razini signifikantnosti od o,o5 ne postoji dovoljno dokaza za odbacivanje nulte hipoteze o homogenosti dugoročnih parametara.

Standardne pogreške procjene parametara modela dane su u uglatim zagradama. P-vrijednost za Hausmanov test specifikacije dana je u oblim zagradama. Zvjezdice ******, označavaju redom: značajnost na razini signifikantnosti od Io\%, 5\% i I\%.

Izvor: izračun autorica. 
TABLICA A5.

Rezultati procjene modela utjecaja reformi tržišta rada na ekonomsku aktivnost za EU-I5 i NMS-I3 (PMG procjenitelj)

\section{Varijabla}

EU-I5

NMS-13

\begin{tabular}{|c|c|c|}
\hline \multicolumn{3}{|c|}{ PMG procjene dugoročnih koeficijenata } \\
\hline lm_reg & $\begin{array}{c}0,291^{* * *} \\
{[0,187]}\end{array}$ & $\begin{array}{l}\text { o,074 } 4^{* * *} \\
{[0,019]}\end{array}$ \\
\hline crisis & $\begin{array}{c}-0,362^{* * *} \\
{[0, I 04]}\end{array}$ & $\begin{array}{c}-0,523^{* *} \\
{[0,204]}\end{array}$ \\
\hline Ind_pro & $\begin{array}{c}\mathrm{I}, 338^{* * *} \\
{[\mathrm{O}, \mathrm{I} 68]}\end{array}$ & $\begin{array}{c}\mathrm{I}, 72 \mathrm{O}^{* * *} \\
{[\mathrm{o}, \mathrm{0} 63]}\end{array}$ \\
\hline \multirow[t]{2}{*}{ act_r $r$} & $\begin{array}{c}\text { o,o32** } \\
{[0,014]}\end{array}$ & $\begin{array}{c}\mathrm{O}, \mathrm{O} 44^{* *} \\
{[\mathrm{O}, \mathrm{OIO}]}\end{array}$ \\
\hline & \multicolumn{2}{|c|}{ PMG procjene kratkoročnih koeficijenata } \\
\hline Faktor korekcije pogreške & $\begin{array}{l}-0,295^{* * *} \\
{[0,046]}\end{array}$ & $\begin{array}{l}-0,442^{* * *} \\
{[0,087]}\end{array}$ \\
\hline$\Delta$ Ind_pro & $\begin{array}{r}\text { O,I6I } \\
{[0,154]}\end{array}$ & $\begin{array}{l}-0,939 \\
{[0,919]}\end{array}$ \\
\hline$\Delta l m \_r e g$ & $\begin{array}{l}- \text { O,O7I*** } \\
{[0,019]}\end{array}$ & $\begin{array}{c}0,009 \\
{[0,035]}\end{array}$ \\
\hline$\Delta a c t \_r$ & $\begin{array}{c}\mathrm{O}, \mathrm{OO} 2 \\
{[\mathrm{O}, \mathrm{O} 2 \mathrm{I}]}\end{array}$ & $\begin{array}{c}0,042 \\
{[0,029]}\end{array}$ \\
\hline \multirow[t]{2}{*}{ konstanta } & $\begin{array}{l}-1,639^{* * *} \\
{[0,273]}\end{array}$ & $\begin{array}{c}-2,945^{* * *} \\
{[0,596]}\end{array}$ \\
\hline & \multicolumn{2}{|c|}{ Hausmanov specifikacijski test } \\
\hline vrijednost & $\begin{array}{c}0,27 \\
(0,99)^{\mathrm{a}}\end{array}$ & $\begin{array}{c}0,28 \\
(0,99)^{b}\end{array}$ \\
\hline
\end{tabular}

${ }^{a}$ Vrijednost u zagradi odnosi se na empirijsku razinu signifikantnosti i označava da na razini signifikantnosti od o,o5 ne postoji dovoljno dokaza za odbacivanje nulte hipoteze o homogenosti dugoročnih parametara, odnosno da je model dobro specificiran.

${ }^{b}$ Vrijednost u zagradi odnosi se na empirijsku razinu signifikantnosti i označava da na razini signifikantnosti od o,o5 ne postoji dovoljno dokaza za odbacivanje nulte hipoteze o homogenosti dugoročnih parametara.

Standardne pogreške procijene parametara modela dane su u uglatim zagradama. P-vrijednost za Hausmanov test specifikacije dana je u oblim zagradama. Zvjezdice *******, označavaju redom: značajnost na razini signifikantnosti od Io\%, 5\% i I\%.

Izvor: izračun autorica. 
TABLICA A6.

Provjera robustnosti baznog modela: DFE procjenitelj

\begin{tabular}{|c|c|c|c|}
\hline & EU-28 & EU-I5 & NMS-13 \\
\hline Faktor korekcije pogreške & $\begin{array}{c}-0,522^{* * *} \\
{[0,050]}\end{array}$ & $\begin{array}{c}-0,256^{* * *} \\
{[0,040]}\end{array}$ & $\begin{array}{c}-0,724^{* * *} \\
{[0,086]}\end{array}$ \\
\hline \multicolumn{4}{|l|}{ Dugoročni koeficijenti } \\
\hline lm_reg & $\begin{array}{c}\mathrm{O}, \mathrm{I} 78^{* * *} \\
{[0,036]}\end{array}$ & $\begin{array}{c}0,209^{* * *} \\
{[0,036]}\end{array}$ & $\begin{array}{c}\text { O,I45 } 5^{* * *} \\
{[0,053]}\end{array}$ \\
\hline crisis & $\begin{array}{c}-0,0354 \\
{[0,102]}\end{array}$ & $\begin{array}{l}-0,389^{* * *} \\
{[0, I I 4]}\end{array}$ & $\begin{array}{l}0,065 \\
{[0,156]}\end{array}$ \\
\hline Ind_pro & $\begin{array}{c}\mathrm{I}, 32 \mathrm{I}^{* * *} \\
{[\mathrm{O}, \mathrm{I} 97]}\end{array}$ & $\begin{array}{c}0,400 \\
{[0,270]}\end{array}$ & $\begin{array}{c}\mathrm{I}, 72 \mathrm{I}^{* * *} \\
{[0,247]}\end{array}$ \\
\hline act_r $r$ & $\begin{array}{c}\mathrm{O}, 039^{* *} \\
{[\mathrm{o}, 018]}\end{array}$ & $\begin{array}{l}\text { O,059*** } \\
{[0,019]}\end{array}$ & $\begin{array}{c}0,007 \\
{[0,024]}\end{array}$ \\
\hline \multicolumn{4}{|l|}{ Kratkoročni koeficijenti } \\
\hline$\Delta I n d \_p r o$ & $\begin{array}{c}-0,174 \\
{[0, I 79]}\end{array}$ & $\begin{array}{c}\mathrm{O}, \mathrm{I9} 8^{*} \\
{[\mathrm{O}, \mathrm{IO} 4]}\end{array}$ & $\begin{array}{c}-0,608^{*} \\
{[0,33 \mathrm{I}]}\end{array}$ \\
\hline$\Delta l m \_r e g$ & $\begin{array}{l}-0,06 \mathrm{I} \\
{[0,025]}\end{array}$ & $\begin{array}{l}-\mathrm{O}, \mathrm{O} 4 \mathrm{I}^{* * *} \\
{[\mathrm{O}, \mathrm{OI} 4]}\end{array}$ & $\begin{array}{c}-0,047 \\
{[0,046]}\end{array}$ \\
\hline$\Delta a c t \_r$ & $\begin{array}{r}\text { O,OII } \\
{[0, \mathrm{OI} 7]}\end{array}$ & $\begin{array}{c}\text { o,oo9 } \\
{[0,010]}\end{array}$ & $\begin{array}{c}\mathrm{O}, \mathrm{O} 2 \mathrm{I} \\
{[\mathrm{O}, \mathrm{O} 29]}\end{array}$ \\
\hline konstanta & $\begin{array}{c}-2,822 \\
{[0,788]}\end{array}$ & $\begin{array}{l}-0,69 \mathrm{I} \\
{[0,43 \mathrm{I}]}\end{array}$ & $\begin{array}{l}-3,469^{* *} \\
{[I, 634]}\end{array}$ \\
\hline Broj opažanja & 299 & I63 & I36 \\
\hline Broj zemalja & 28 & 15 & I3 \\
\hline
\end{tabular}

Izvor: izračun autorica. 


\section{REFERENGE}

I. Aleksynska, M., 20I4. Deregulating labour markets: How robust is the analysis of recent IMF working papers?, Conditions of Work and Employment Series, Br. 47. Geneva: International Labour Office.

2. Alesina, A., Ardagna, S. i Trebbi, F., 20o6. Who adjusts and when? On the political economy of reforms. IMF Staff Papers, 53(Special Issue).

3. AMECO. Dostupno na: 〈http://ec.europa.eu/economy_finance/db_indicators/ameco/indexen.htm>.

4. Arpaia A. [et al.], 2007. Quantitative assessment of structural reforms: Modelling the Lisbon strategy. Industrial Policy and Economic Reforms Papers, Br. 5.

5. Babetskii, I. i Campos, N. F., 2007. Does Reform Work? An Econometric Examination of the Reform-Growth Puzzle. IZA Discussion Paper, Br. 2638.

6. Bahovec, V. i Erjavec, N., 2009. Uvod u ekonometrijsku analizu. Zagreb: Element.

7. Barnes, S. [et al.], 20I3. The GDP Impact of Reform: A Simple Simulation Framework. OECD Economics Department Working Papers, Br. 834. Paris: OECD Publishing.

8. Bergsten, C. F. i Williamson, J., 1994. "Introduction" u J. Williamson, ur. Political Economy of Policy Reform, str. I-8. Washington, DC: Institute for International Economics.

9. Blackburne, E. F. i Frank, M. W., 2007. Estimation of nonstationary heterogeneous panels. The Stata Journal, 7(2), str. 197-208.

Io. Bouis, R. [et al.], 20I2. The Short-Term Effects of Structural Reforms: An Empirical Analysis. OECD Economics Department Working Papers, Br. 949. Paris: OECD.

II. Bouis, R. i Duval, R., 20II. Raining Potential Growth after the Crisis: A Quantitative Assessment of the Potential Gains from Various Structural Reforms in the OECD Area and Beyond. OECD Economics Department Working Papers, Br. 835. Paris: OECD.

I2. Buti, M. [et al.], 2OIo. Reforms and Re-Elections in OECD Countries. Economic Policy, 25(6I), str. 6III6. doi: IO.IIII/j.I468-0327.2009.00237.X

I3. Cacciatore, M., Duval, R. i Fiori, G., 20I2. Short-Term Gain or Pain? A DSGE Model-Based Analysis of the Short-Term Effects of Structural Reforms in Labour and Product Markets. OECD Economics Department Working Papers, Br. 948. Paris: OECD.

I4. Chang, H., 20II. Institutions and economic development: theory, policy and history. Journal of Institutional Economics, 7(4), str. 473-498. doi: 10.1017/SI744137410000378

15. Drazen, A. i Easterly, W., 200I. Do Crises Induce Reform? Simple Empirical tests of Conventional Wisdom. Economics and Politics, I3(2), str. 129-157. doi: I0.IIII/I468-0343.00087

I6. Duval, R. i Elmeskov, J., 2006. The Effects of EMU on Structural Reforms in Labor and Product Markets. ECB Working Paper, Br. 596.

17. ECB, 2012. Euro Area Labour Markets and the Crisis. Structural Issues Report. Bruxelles: ECB.

I8. Economic freedom of the world. Dostupno na: 〈http://www.freetheworld.com/〉.

19. Engle, R. F. i Granger, C. W. J., 1987. Co-integration and error correction: representation, estimation and testing. Econometrica, 55(2), str. 25I-76. doi: 10.2307/1913236

20. European Commission, 2013. European Competitiveness Report: Towards Knowledge-Driven Reindustrialisation. Commission Staff Working Document SWD(2013)347 final, European Union.

21. European Commission, 20I4. Reindustrialising Europe - Member States' Competitiveness Report 20I4. Commission staff working document, SWD(2OI4) 278, A Europe 2020 Initiative, European Union.

22. Eurostat. Dostupno na: 〈http://http://epp.eurostat.ec.europa.eu〉.

23. Everaert, E. i Schule, W., 2008. Why It Pays to Synchronize Structural Reforms in the Euro Area Across Markets and Countries. IMF Staff Papers, 55(2). doi: Io.IO57/imfsp.2008.6

24. Gomes, S. [et al.], 20II. Structural Reforms and Macroeconomic Performance in the Euro Area Countries: A Model-based Assessment. European Central Bank. Working Paper, Br. 1323.

25. Gwartney, J., Lawson, R. i Block, W., 1996. Economic freedom of the world 1975-1995. Vancouver, BC. Fraser Institute. 
26. Hobza, A. i Mourre, G., 20IO. Quantifying the potential macroeconomic effects of the Europe 2020 strategy: stylized scenarios. ECFIN Economic Papers, Br. 424.

27. Høj, J. [et al.], 2006. An Empirical Investigation of Political Economy Factors Behind Structural Reforms in OECD Countries. OECD Economic Studies, Br. 42.

28. IMF, 2004. Fostering structural reforms in industrial countries. World Economic Outlook. Advancing Structural Reforms.

29. LABREF, European Commission, Directorate General for Economic and Financial Affairs and Economic Policy Committee. Dostupno na: <http://ec.europa.eu/economy_finance/db_indicators/labref/index_en.htm>.

30. OECD, 2008. Handbook on Constructing Composite Indicators: Methodology and User Guide. OECD Statistics Working Paper, STD/DOC (2005)3.

31. OECD, 2012. OECD Economic Surveys Euro Area. Paris: OECD.

32. Persyn, D. i Westerlund, J., 2008. Error Correction Based Cointegration - Tests for Panel Data. Stata Journal, str. 8-2.

33. Pesaran, H., Shin, Y. i Smith, R. P., 1999. Pooled Mean Group Estimation of Dynamic Heterogeneous Panels. Journal of the American Statistical Association, 94, str. 62I-634. doi: IO.IO80/OI62I459.I999.IO474I56

34. Pesaran, M. H. i Smith, R. P., 1995. Estimating Long-Run Relationships from Dynamic Heterogenous Panels. Journal of Econometrics, 68, str. 79-II3. doi: Io.IOI6/O304-4076(94)oI644-F

35. Tompson, W. i Dang, T., 20IO. Advancing Structural Reforms in OECD Countries: Lessons from Twenty Case Studies. OECD Economics Department Working Papers, Br. 757.

36. Turrini, A. [et al.], 20I4. A Decade of Labour Market Reforms in the EU: Insights from the LABREF Database. IZA Policy Paper, Br. 88.

37. Westerlund, J., 2007. Testing for error correction in panel data. Oxford Bulletin of Economics and Statistics, 69, str. 709-748. doi: I0.IIII/j.I468-0084.2007.00477.x

38. World Bank, 20II. Employment Protection Legislation and Labor Market Outcomes: Theory, Evidence and Lessons for Croatia. Croatia Policy Notes. Washington: The World Bank Document. 